\title{
Equity Implications Of A Corporate Tax Reform
}

Vassilis Patsouratis, (Email: patsour@aueb.gr), Athens University of Economics and Business, Greece

\begin{abstract}
The paper attempts to access the likely distributional effects of the corporate tax reform in Greece. The major distributional consequences of introducing a new corporate tax system upon dividend policy, on the share prices, the shifting and incidence of the tax and the removal of the existing tax inequities.
\end{abstract}

The equity implications from the introduction of the new system could be summarized as follows: The new system favours distribution to less degree than the old system which means that under the latter a larger proportion of income could be closely adjusted to taxable capacity of the individual shareholder. On the other hand, under the new system corporate income is taxed by a flat and not by a progressive tax rate as the principle of taxable capacity would suggest. If we accept that higher payout ratios have a positive effect upon share prices then, since the new system favours distribution to a less degree than the old system it would have a negative effect upon share prices. Finally, the greater tax burden on the corporation level, under the new system, provides the corporation with a greater incentive to shift the tax.

\section{Introduction}

ince the mid-1980's there has been a corporate tax reform either in the form of broadening the tax base or the reduction of the tax rate in many OECD countries. Many explanations can be given for such activity, apart from competition for tax revenues. It is possible, for example, to point to the general trend towards some concept of «tax neutrality» or «a level playing-field» throughout the developed world during the 1980's in relation to all taxes and not simply corporate taxes (OECD, 1991, J. Kay, 1990). However, despite all the activities, it is in fact not easy to discern a clear trend in the way in which governments have viewed particular aspects of their tax laws.

On August 1992 the Greek government passed a Tax Reform Act. This Tax Reform Act made sweeping changes in the structure of the Greek Tax System, by curbing tax preferences and using the room thus created to lower marginal tax rates. In this way, it was hoped incentives to work, save and invest would be enhanced and economic performance would be improved.

Particularly in the field of corporate income taxation (CIT) the reform was very radical since the system which has been employed since 1958 was replaced. A new system of corporate taxation, not employed by any other country today, took the place of the dividend deduction system. The innovative element of that system is the exclusion of dividend income from personal income taxation. In other words, corporate income is taxed only by the corporate tax irrespective if it is retained or distributed. Thus despite the long discussions of the last years on behalf of the full integration system which actually implies the abolition of corporate taxation the Greek government selected the corporate income tax only to be levied on corporate income. The paper attempts to assess the likely distributional effects of this tax reform. Section II outlines the major changes implemented by the Tax Reform Act. Section III deals with equity considerations under corporate taxation followed in section IV by the major distributive consequences of implementing that reform. Section V provides some conclusions.

Readers with comments or questions are encouraged to contact the author via email. 


\section{A Brief Overview Of The Greek Corporate Tax System}

Greece treated corporate profits by a method different from that used in all other countries. The corporate tax was levied only on retained earnings, whereas dividends were taxed under the personal tax rates. Under the new system the tax base for corporate taxation includes both distributed and undistributed profits. This constitutes the primary operational different between the two systems.

Under the previous system distributed profits were not subject to corporate taxation but the company withheld the corresponding individual income tax and gave that to the government. Therefore the only link between the corporate and personal tax was the requirement on a corporation to act as a withholding agent for individual income tax due to dividend income paid the corporation. This withholding tax was used as a means of fighting tax evasion. The rate of withhold tax varied according to the type of shares. The corporation withheld 35\% for registered shares and 41 percent for bearer shares both quoted with the Athens Stock Exchange (ASE), whereas these rates were correspondingly 43 and 47 per cent for dividends from shares not quoted with the ASE. For dividends from bearer shares not quoted with ASE the 47 percent rate was the final tax rate levied on them, whereas for dividends from the other types of shares the taxpayer had the option to incorporate or not these with the rest of his income to the taxed under the progressive personal income tax scale.

The shareholder was enlisted to a per company exemption of $50.000 \mathrm{drs}$ and an overall exemption of 200.000 drs. These exemptions were provided to dividend income generated from shares listed with the Athens Stock Exchange, as a means of inducing investors to invest on stock shares listed with the Athens Stock Exchange.

This system of dividend taxation can be criticized in three respects for lack of equity or efficiency. First, the different treatment between retained and distributed profits has been virtually neutral between dividends and retained profits, but the lack of capital gains tax favors retention, which can be used as a tax shelter. This discrimination provides two undesirable effects: first, it provides the shareholders with a tax shelter, which is undesirable, particularly if income from movable capital is concentrated on high income classes, and second, this discrimination interferes in the good functioning of the capital market. The provision of exemption of $50.000 \mathrm{drs}$ per firm and an overall 200.000 drs is not justified from equity point of view if we take into consideration that the recipients of these dividends belong to the higher income classes. In addition to that, that provision discriminates against shares not quoted with ASE.

The second provision for the sake of the development of the capital market is concerned with the different tax coefficients applying on dividends from shares quoted or not and registered or bearer. There was a discrimination against shareholders who hold bearer shares unquoted with ASE. They were not allowed to include their income from these shares within the income from other sources, but the withholding tax was the final tax levied on this income. If the income from other sources was beyond an amount then they were taxed more heavily than if they were allowed to include all income together to be taxed with the personal income tax scale.

\section{Equity Considerations Under Corporate Taxation}

This section attempts a judgment of the two systems under the horizontal and vertical equity principles. The first requires the «equals should be treated equally», whereas the second requires the proper division of the tax shares among individuals with different economic capacity, as a means of contributing to a more equitable distribution of income. Of course, the assumption about the incidence and shifting of the corporate taxation is crucial and the existence or not of capital gains tax plays a significant role.

If CIT is not shifted it produces equity between the shareholding class as a whole and the rest of the community by taxing undistributed profits, on the one hand, and it produces inequity between rich and poor shareholders, since it violates the vertical principle, on the other hand. We begin with the classical system for example, suppose two shareholders, the first, with low marginal personal tax rate tpL and the second with high tpH. Since the ability to pay of the shareholders is reflected in the sum of dividends and retained profits, the total final tax liability does not conform to the vertical equity principle. Under the classical system the final tax rate applied to 
both retained and distributed profits is for the poor shareholder $\mathrm{tL}=\mathrm{tc}+\mathrm{tpL}(\mathrm{I}-\mathrm{tc})$ and for the rich $\mathrm{tH}=\mathrm{tc}+\mathrm{tpH}(\mathrm{I}$ - tc). From these two relationships we see that the corporate tax rate, tc, is the same for both shareholders despite the fact that their economic capacity is different. In other words, we have the same treatment of unequal, namely, a violation of the vertical equity principle. From the above tax liability formulas we also see that the introduction of CIT imposes an extra tax rate which is proportionally greater for the low income shareholder than on the high income shareholder. This can be seen if we compare the combined corporate and individual tax now paid with the tax which would be paid if only the income tax was applied. These differences are tc (I - tpL) and tc (I - tpH) for the low and high income shareholder respectively, and the former is greater than the later (see appendix). Therefore, the classical system violates the vertical equity principle.

The dividend-paid-deduction system favors distribution relative to the classical system (for a given revenue), which involves that a higher amount of profits is taxed under the progressive personal tax scale. In that respect this system is less regressive than the classical system, since it contributes to a fairer tax structure. As far as the retained amount of profits is concerned the same holds as in the classical system. Therefore this system conforms with vertical and horizontal equity but only for distributed profits. If all profits were distributed and taxed under the personal income tax rate this system awards with horizontal and equity principles since all the corporate income of the shareholders will be taxed like the income of other taxpayers. Therefore, there is no different treatment between shareholders and non-shareholders.

Under the new Greek system corporate income is exempt from personal taxation. This is a scheduler type of taxation which violates the ability to pay principle. Its main advantage is that there is no dividend double taxation.

We assume now that the CIT is shifted and that the management, in making price decisions, takes into account the total tax liability, namely, taxes paid by both the corporation and the shareholders. Under the classical system these assumptions result in eliminating the economic double taxation of dividends. Under the dividend-paiddeduction system the shareholders would be in a better position than interest income taxpayers. Finally under the new system neither the corporation nor the shareholders pay any taxes.

\section{Distributional Effects}

The major distributive consequences of introducing the new system are to be found in: (a.) the impact of the new system upon dividend policy, (b.) the impact on the share prices, (c) the shifting and incidence of the Greek CIT, and (d.) the removal of the existing tax inequities.

\section{a. Dividend Policy}

There arises the question of how dividend policy would be affected by substituting the new system for the dividend-paid-deduction system. A number of effects of opposing direction might be generated which make any prediction difficult. The effects whose significance seems most reliable are: (1) the value of discriminatory variable against or in favor of distribution, (2) the shelter effect, that is, the incentive utilized by high income shareholders to retain corporate profits in order to reduce personal tax liabilities, and (3) the treatment of equity and debt financing.

\section{$a_{1}$ The Tax Discriminator y Variable}

The value of the tax discriminatory variable under the existing system is given by the formula,

$\Theta o=1-t p / I-t c$

Under the new system this formula becomes as follows: $\Theta n=1$

Where tp and tc is the rate of personal and corporate tax. The most representative value of tp is 35 per cent. 
Table 1 shows the values which the tax discriminatory variable may take under the old and new systems.

Table 1

Tax Discriminatory Variable's Values

\begin{tabular}{|c|c|c|c|c|c|}
\hline \multicolumn{5}{|c|}{ Old System } & New System \\
\hline tp & tc & $\Theta$ & tc & $\Theta$ & $\Theta$ \\
\hline 40 & 45 & 1.09 & 40 & 1.00 & 1.00 \\
\hline 45 & & 1.00 & & 0.91 & \\
\hline 50 & & 0.90 & & 0.83 & \\
\hline
\end{tabular}

From the above table we see that the most representative value of $\theta$ under the old system was higher than one, whereas under the new system it is equal to one. This implies that the cost of retained earnings was higher under the old system, which induced corporations to distribute higher amount of profits than under this system, whereas the new tax system is neutral between retention and distribution.

\section{$\underline{\text { Implications From Higher Payout Ratios }}$}

From the above discussion we observed that under the old system a larger proportion of income could be closely adjusted to the taxable capacity of the individual shareholders. Therefore, the old system would result in a fairer tax structure in which different types of income are taxed more nearly on uniform base.

In addition, in the absence of a capital gains tax, as in Greece, higher payout ratios means that fewer capital gains are created, which decrease shareholder's wealth.

On the other hand, under the new system the principles of the horizontal and vertical equity are violated since the income of shareholders from dividends are not added to their income from other sources. Shareholders, whose income from various sources is added, could be taxed by more than corporate income tax of 35 per cent, thus enjoying a tax reduction. On the other hand, shareholders charged by low tax rate of the personal income tax will receive the burden of the new system. In other words, the new system taxes incomes from profits with a flat and not by a progressive tax rate as the principle of taxable capacity would suggest.

Higher payout ratios imply less available funds to the company for financing investment programs and assuming that more investment means more growth whose benefit is spread over the community as a whole, the new system might be more regressive than the old one assuming that the recipient of dividends are in the top-half of the income bracket scale. However, greater dividend does not only affect national income through investment decisions, but it also affects it through consumption and tax revenue. Thus, an increase in dividends may lead to a decrease in investment, which will tend to lower the national income, but in the personal sector one may expect an increase in consumption, which tends to raise national income. Furthermore, the increase in the tax revenues may lead to additional government spending, which will also tend to raise the national income. Thus, the final effect on national income may be either positive or negative depending on the spending propensities of consumption of individuals and government.

\section{a $\quad$ The Shelter Effect}

In countries where individual income tax rates substantially exceeds the rate of corporate tax, a company would provide a shelter for individuals whose marginal rate of income tax exceeds the CIT rate on profits retained by the company. This was the case of Greece where, for many years, the top value of the marginal personal tax rate was 
Table 2

Tax Consequences For Shareholders With Different Personal Income Tax Rates

\begin{tabular}{|c|c|c|c|c|}
\hline & \multicolumn{2}{|c|}{ Old System } & \multicolumn{2}{|c|}{ New System } \\
\hline & Payout Ratio: $40 \%$ & Payout Ratio: $60 \%$ & Payout Ratio: $40 \%$ & Payout Ratio: $60 \%$ \\
\hline 1. Corporate profits & 1000 & 1000 & 1000 & 1000 \\
\hline 2. Corporation tax $(45 \%)$ & 329 & 247 & 450 & 450 \\
\hline 3.After tax profits & 671 & 753 & 550 & 550 \\
\hline 4.Retained earnings & 403 & 301 & 330 & 220 \\
\hline 5. Dividends & 268 & 452 & 220 & 330 \\
\hline 6. Personal income tax at $20 \%$ & 54 & 90 & - & - \\
\hline 7.Net dividends (5-7) & 204 & 362 & 220 & 330 \\
\hline 8. Total gov't revenue $(2+6)$ & 383 & 337 & 450 & 450 \\
\hline 9. Personal income tax at $50 \%$ & 134 & 226 & - & - \\
\hline 10.Net dividends 95-9) & 134 & 271 & 220 & 330 \\
\hline 11. Total gov't revenue $(2+9)$ & 463 & 473 & 450 & 450 \\
\hline
\end{tabular}

Note: The formula $\mathrm{T}=\mathrm{K}(\mathrm{P}-\mathrm{D})$ and $\mathrm{D}=\mathrm{g}(\mathrm{P}-\mathrm{T})$ were used respectively to calculate amount of taxes and dividends under the old system, where $\mathrm{K}$ denotes the corporate tax rate, $\mathrm{g}$ the payout ratio (dividends to after tax profits) and $\mathrm{P}$ profits.

higher than 50 per cent, whereas the corporate tax rate was less than 50 per cent. In addition, the absence of a capital gains tax makes this incentive even stronger.

On the other hand, under the new system, corporations do not have a direct incentive to increase or decrease dividends out of any given amount of profits because their tax liabilities do not change by changing the distributed amount. However, the old system, where corporations were taxed only on retained profits, provided such an incentive because an increase in dividends reduces the amount of corporate income tax. This reasoning is based on the assumption that management is concerned with the corporate tax liability only and not with the total tax liability. It does not seem to be a realistic assumption particularly, for Greece, where the majority of the corporations are controlled and ruled by families.

\section{$a_{3}$ Debt And Equity Financing}

The new system, as the old one, does not introduce economic double taxation of dividends. Thus it is neutral between equity and debt financing. On the other hand, a corporation had to earn 100 Drs in order to pay same for dividends or interest. Under the new system, this symmetry in the treatment of interest and dividends is abolished. A corporation that earns 100 Drs in order to pay the same for interest should now earn 154 Drs in order to pay 100 Drs. for dividends (corporate tax rate 35 per cent). This means that the new system introduced nonsymmetric tax treatment of interest and dividends against the latter payments. In other words, a corporation has now an incentive to prefer debt finance rather than equity.

\section{b. Price Of Shares}

We continue our discussion about the distributional effects of the tax reform by including the effect which the reform has upon the price of shares. Since shares reflect, to some extent, the wealth of the owner, the change in their prices has an effect upon their total wealth. 
Two effects may well be generated. The first is concerned with the relationship between the level of distribution and the price of shares. It is argued that shareholders who prefer more dividend rather than retained profits are willing to pay a higher price for such shares. Unfortunately, there is no well-established study dealing with this relationship in Greece. However, two simplified ones exist. The earlier, concerning the years 1962-66, reaches the conclusion that a positive relationship exists between share prices and the level of distribution (G. Papoulias, 1971) the more recent one, concerning the years 1975-78, concludes that the main cause, that is, 83 per cent, of the fall in the price of shares during the period in question, was the absence of any dividend distribution, whereas on the other hand, the main cause of the rise, that is $70 \%$, was a higher level of current or prospective dividends (A. Nicolopoulos, 1978). Thus, in the light of these findings we may be allowed to conclude that higher payout ratios have a positive effect upon share prices. Since the new system favors distribution to a less degree than the old system it would have a negative effect upon share prices. Assuming firms with identical expected future profits we accept that the prices of shares with currently high payout ratios rising more than those with currently low payout ratios. In addition, it is reasonable to assume that shareholders who put more emphasis in the income through dividends rather than capital gains belong to low-income classes rather to high-income classes. Therefore, the change of the tax system will favors high income shareholders greater than low-income shareholders.

Finally, it can be argued that the replacement of the dividend-paid-deduction system by the new system did not decrease the attraction of company stock relative to other savings media since both systems are neutral on the return of corporate equity. Consequently, the attractiveness of stocks relative to other savings media remains the same not influencing the price of shares.

\section{c. Incidence And Shifting Of The CIT}

The discussion of tax shifting is related to the assumptions one makes regarding the tax rates applied, the management behavior and the reverse shifting hypothesis. The higher tax rate under the old system provides the corporation with a greater incentive to shift the tax. Under this system the distributed profits were not taxed at the corporate level; therefore, the chances of shifting the tax onto distributed profits, were eliminated. On the other hand, if we assume that the management takes into account the level of tax on distribution, as well as, and shifts it, and then the shareholders receive a tax-free income.

Table 2 shows that under the new system the whole tax is imposed on the corporation (line 2) and zero tax on the shareholder (lines 6 and 9). This implies that the new system gives little inducement to reverse shifting. On the other hand, the old system by reducing tax collections at the corporate level would encourage reverse shifting.

\section{d. Removal Of Existing Tax Unneutralities}

Under the old system dividend taxation implied two kinds of inequities:

First, the 50.000 Drs or 200.000 Drs exemption from dividend income created inequities. First between shareholders who received dividends from shares quoted with Athens Stock Exchange and those who received dividends from shares not quoted with Athens Stock Exchange. Second, between high and low income shareholders who received dividend from shares quoted with Athens Stock Exchange since the exemption granted is the same for both classes of shareholders.

Second, shareholders who received dividends from bearer shares not quoted with Athens Stock Exchange were taxed at 47 per cent tax rate and were not allowed to include their income from dividends with their other income. This treatment involves two kinds of inequity. First, it violates the principle of global taxation since it deprives the right of a category of shareholders of including their income from dividend along with the rest of their income and at the same time it provides other shareholders with the option to decide to include or not their income from dividends along with the rest of their income. This may have as a consequence that low-income shareholders were overtaxed. 
On the other hand, the new system involves an inequity among taxpayers who have income from corporations and other sources and the rest taxpayers who have income from more than one source. The first category is allowed to split its income and thus to avoid high marginal income tax, whereas the second is taxed for its all income under the personal income tax scale. In addition, under the new system, it is very possible, that lowincome shareholders to be taxed for their income from corporations under higher tax rate.

\section{Conclusions}

The recent corporate tax reform in Greece made radical changes in the taxation of the corporate income. The new system increased the tax burden at the corporation level through the extension of the tax base to include both retained and distributed profits, introduced a discrimination against equity finance and avoids, as did the old system, double taxation of dividends. The distribution of profits is no more affected, directly, by taxation and consequently the policy followed by firms at that point would reflect their real priorities.

The equity implications from the introduction of the new system could be summarized as follows: The new system favors distribution to less degree than the old system which means that under the latter a larger proportion of income could be closely adjusted to taxable capacity of the individual shareholder. On the other hand, under the new system corporate income is taxed by a flat and not by a progressive tax rate as the principle of taxable capacity would suggest. If we accept that higher payout ratios have a positive effect upon share prices then, since the new system favors distribution to a less degree than the old system it would have a negative effect upon share prices.

Finally, the greater tax burden on the corporation level, under the new system, provides the corporation with a greater incentive to shift the tax.

\section{Bibliography}

1. Commission of the European Taxation, "Report of the Committee of Independent Experts on Company Taxation," March 1992.

2. $\quad$ European Commission, "Report of Independent Experts on Corporate Taxation," 1992, C 1-74-92152-FR-C.

3. Evans, O. and L. Kenward, "Macroeconomic Effects of Tax Reform in the United States," IMF Staff Papers, Vol. 35, No 1, 1988, pp. 141-165.

4. Hubbard, R, "Corporate Tax Integration: A View from the Treasury Department," Journal of Economic Perspectives, Vol. 7, number 1, 1993, pp. 115-132.

5. Kay, J, “Tax Policy: A Survey,” The Economic Journal, vol. 100, No 399, 1990, pp. 18-75.

6. Khalilzadeh-Shirazi, J and A. Shah, "Tax Policy Issues for 1990's," The World Bank Economic Review, 1991, pp. 459-471.

7. Nicolopoulos, A, "Measures for the Creation of a Large Capital Market," Nafteboriki, 1978, Athens

8. $\quad O E C D$, "Taxing Profits in a Global Economy," 1991.

9. Papoulias, "G, Games of the Share Prices," Economicos Tachydromos, 1971, Athens.

10. Patsouratis, V, “A New Corporate Tax System,” Intertax, 1995, pp. 449-452.

11. Toshiaki Tachihakaki, "The Japanese Tax Reform; Efficiency Versus Equity," Public Finance, Supplement, vol. 47, 1992, pp. 271-285.

\section{Appendix}

The total tax liability without corporate income tax is defined as follows:

$* \mathrm{t}^{\mathrm{L}}=\mathrm{tp}^{\mathrm{L}}(1)$ for low income taxpayer

$* \mathrm{t}^{\mathrm{H}}=\mathrm{tp}^{\mathrm{H}}(2)$ for high income taxpayer

where tp is personal income tax rate

The total tax liability with corporate income tax is estimated as follows:

$\mathrm{t}^{\mathrm{L}}=\mathrm{tc}+\mathrm{tp}^{\mathrm{L}}(1-\mathrm{tc})$

$\mathrm{t}^{\mathrm{H}}=\mathrm{tc}+\mathrm{tp}^{\mathrm{H}}(1-\mathrm{tc})$

where tc is corporate income tax rate 
Subtracting (1) from (3) and (2) from (4) we have:

$: \mathrm{t}^{\mathrm{L}}-* \mathrm{t}^{\mathrm{L}}=\mathrm{tc}\left(1-\mathrm{tp}^{\mathrm{L}}\right)$

$: \mathrm{t}^{\mathrm{H}}-* \mathrm{t}^{\mathrm{H}}=\mathrm{tc}\left(1-\mathrm{tp}^{\mathrm{H}}\right)$

Since $\operatorname{tp}^{\mathrm{H}}>\mathrm{tp}^{\mathrm{L}}$

we have: $\mathrm{t}^{\mathrm{L}}-\mathrm{t}^{\mathrm{L}}>\mathrm{t}^{\mathrm{H}}-* \mathrm{t}^{\mathrm{H}}$

Notes 